\title{
Augmentation of Pulmonary Epithelial Cell IL-8 Expression and Permeability by Pre-B-cell Colony Enhancing Factor Hailong Li ${ }^{\dagger 1,2}$, Peng Liu ${ }^{\dagger 1,2}$, Javier Cepeda1,2, Deyu Fang2,3, R Blaine Easley4, Brett A Simon ${ }^{4,5}$, Li Qin Zhang ${ }^{1,2}$ and Shui Qing Ye*1,2
}

Address: ${ }^{1}$ Department of Surgery, University of Missouri School of Medicine, Columbia, MO 65212, USA, ${ }^{2}$ Department of Molecular Microbiology and Immunology, University of Missouri School of Medicine, Columbia, MO 65212, USA, ${ }^{3}$ Department of Otolaryngology, University of Missouri School of Medicine, Columbia, MO 65212, USA, ${ }^{4}$ Department of Anesthesiology and Critical Care Medicine, The Johns Hopkins University, Baltimore, MD 21205, USA and ${ }^{5}$ Department of Medicine, The Johns Hopkins University, Baltimore, MD 21205, USA

Email: Hailong Li - lihai@health.missouri.edu; Peng Liu - liup@health.missouri.edu; Javier Cepeda - cepedaj@health.missouri.edu; Deyu Fang - fangd@health.missouri.edu; R Blaine Easley - beasley@jhmi.edu; Brett A Simon - bsimon@jhmi.edu;

Li Qin Zhang - zhanglq@jhmi.edu; Shui Qing Ye* - yes@health.missouri.edu

* Corresponding author †Equal contributors

Published: 22 September 2008

Journal of Inflammation 2008, 5:15 doi:10.1186/1476-9255-5-15
Received: 13 April 2008

Accepted: 22 September 2008

This article is available from: http://www.journal-inflammation.com/content/5/I/I5

(c) 2008 Li et al; licensee BioMed Central Ltd.

This is an Open Access article distributed under the terms of the Creative Commons Attribution License (http://creativecommons.org/licenses/by/2.0), which permits unrestricted use, distribution, and reproduction in any medium, provided the original work is properly cited.

\begin{abstract}
Background: Previous studies in our lab have identified Pre-B-cell colony enhancing factor (PBEF) as a novel biomarker in acute lung injury (ALI). The molecular mechanism of PBEF involvement in the pathogenesis of $\mathrm{ALI}$ is still incompletely understood. This study examined the role of PBEF in regulating pulmonary alveolar epithelial cell IL-8 expression and permeability.
\end{abstract}

Methods: Human pulmonary alveolar epithelial cells (cell line and primary cells) were transfected with human PBEF CDNA or PBEF siRNA and then cultured in the presence or absence of TNF $\alpha$. PBEF and IL-8 expression were analyzed by RT-PCR and Western blotting. In addition, changes in pulmonary alveolar epithelial and artery endothelial cell barrier regulation with altered PBEF expression was evaluated by an in vitro cell permeability assay.

Results: Our results demonstrated that, in human pulmonary alveolar epithelial cells, the overexpression of PBEF significantly augmented basal and TNF $\alpha$-stimulated IL-8 secretion by more than 5 to IO-fold and increased cell permeability by $>30 \%$; the knockdown of PBEF expression with siRNA significantly inhibited basal and TNF $\alpha$-stimulated IL- 8 secretion by $70 \%$ and IL- 8 mRNA levels by $74 \%$. Further, the knockdown of PBEF expression also significantly attenuated TNF $\alpha$ induced cell permeability by $43 \%$. Similar result was observed in human pulmonary artery endothelial cells.

Conclusion: These results suggest that PBEF may play a vital role in basal and TNF $\alpha$-mediated pulmonary inflammation and pulmonary epithelial barrier dysfunction via its regulation of other inflammatory cytokines such as IL-8, which could in part explain the role of PBEF in the susceptibility and pathogenesis of ALI. These results lend further support to the potential of PBEF to serve as a diagnostic and therapeutic target to ALI. 


\section{Background}

Acute lung injury (ALI) is characterized by pulmonary inflammation, non-cardiogenic edema, and severe systemic hypoxemia. Acute respiratory distress syndrome (ARDS) is the severe form of ALI [1,2]. One of the earliest manifestations of ALI is a diffuse intense inflammatory process and damage to both endothelial and epithelial cell barriers, resulting in marked extravasation of vascular fluid into the alveolar airspace [3]. A number of inflammatory cytokines including tumor necrosis factor-alpha (TNF $\alpha$ ) and interleukin 8 (IL-8) can induce or aggravate the inflammation of endothelial and epithelial cells, leading to this barrier dysfunctions [4]. The mortality and morbidity of ALI/ARDS remain high since the etiology and molecular pathogenesis are still incompletely understood.

Our previous study, based on extensive microarray gene expression profiling in canine, murine, and human ALI, revealed pre-B-cell-colony-enhancing factor (PBEF) as a significantly upregulated gene [5]. Analysis of single nucleotide polymorphisms (SNPs) in the PBEF gene proximal promoter region indicated that a GC haplotype had a higher risk of ALI while a TT haplotype may have a lower risk of ALI [5]. Our findings were confirmed and extended by Bajwa et al [6], who showed that the PBEF T-1001G variant allele and related haplotype are associated with increased odds of developing ARDS and increased hazard of intensive care unit mortality among at-risk patients. In contrast, the C-1543T variant allele and related haplotype are associated with decreased odds of ARDS among patients with septic shock and better outcomes among patients with ARDS. In a mechanistic study, we found that PBEF is critically involved in thrombin-induced lung endothelial cell barrier dysregulation [7].

The objective of this study was to further elucidate the role of PBEF in pulmonary epithelial cell inflammation and barrier regulation since impaired alveolar epithelial fluid transport is also a characteristic feature in patients with ALI and has been associated with increased morbidity and mortality [4]. Using A549 human pulmonary alveolar epithelial cells and primary bronchial airway epithelial cells, we assessed the effect of PBEF knockdown with PBEF-specific silencing RNA (siRNA) and the effect of PBEF overexpression on TNF $\alpha$-mediated IL- 8 production and on cellular barrier function. Effect of the altered PBEF expression on basal or TNF $\alpha$ stimulated primary human pulmonary artery endothelial cells permeability was also examined to indirectly validate the similar results in the A549 cell line. Study of the role of PBEF in TNF $\alpha$-mediated pulmonary cell IL-8 production and resultant barrier dysfunctions may help elucidate the molecular mechanisms underlying the role of PBEF in the susceptibility and pathogenesis of ALI.

\section{Methods \\ Materials}

Rabbit anti-human IL-8 polyclonal antibody (Cat. No. sc7922, Santa Cruz, California, USA) and mouse antihuman $\beta$-actin monoclonal antibody (Cat. No. A1978) were obtained from Sigma-Aldrich (St. Louis, MO, USA). Rabbit anti-human PBEF polyclonal antibody was from Bethyl Laboratories, Inc. (Cat. No. A300-372A, Montgomery, TX, USA). Total mouse lung RNA was from Stratagene (Cat. No. 736511, La Jolla, CA, USA). Recombinant human TNF $\alpha$ (Cat. No. 210-TA) was from R\&D Systems Inc. (Minneapolis, MN, USA). Superscript III Reverse Transcriptase (Cat. No. 18080044), Platinum Taq DNA polymerase (Cat. No. 10966018) was from Invitrogen (Carlsbad, CA, USA). Tricine was purchased from the Sigma-Aldrich (Cat. No. T0377, St. Louis, MO, USA). Sources of other key reagents are specified in the relevant text.

\section{Cell culture}

Human A549 cells, a lung carcinomatous type II alveolar epithelial cell line, were obtained from ATCC (Cat. No. CCL-185 ${ }^{\mathrm{TM}}$, Manassas, VA) and maintained in a Dulbecco's Modified Eagle's Medium supplemented with $10 \%$ fetal bovine serum, $2 \mathrm{mM}$ glutamine, and penicillin/ streptomycin. Primary human lung small airway epithelial cells (Cat. No. CC-2547) were obtained from Lonza (Walkersville, MD, USA) and maintained in a small airway epithelial cell basal medium (Cat. No. CC-3119) with Supplement \& Growth factors (Cat. No. CC-4124). Primary human pulmonary artery endothelial cells (HPAEC, Cat. No. CC-2530) were obtained from Cambrex Bio Science Inc. (Walkersville, MD, USA) and maintained in EGM $^{\mathrm{TM}}$-2 Endothelial Cell Medium-2 (Cat. No. CC-4176). All cells were cultured at $37^{\circ} \mathrm{C}$ in a humidified atmosphere of $5 \% \mathrm{CO}_{2}, 95 \%$ air. Cells from each primary flask were detached with $0.05 \%$ trypsin, resuspended in fresh culture medium, and seeded into 6-well plates for Western blot and RT-PCR analysis or seeded into the culture inserts for in vitro cell permeability assays.

\section{Transfection of PBEF siRNA into human A549 cells, primary human lung small airway epithelial cells and primary HPAEC}

PBEF stealth siRNA was designed based on the human PBEF cDNA reference sequence (NM_005746.1) using the BLOCK-iT ${ }^{\mathrm{Tm}}$ RNAi Designer (Invitrogen, Carlsbad, CA, USA). Using GFP-labeled non-specific siRNA, we first optimized the conditions for human A549 cells transfection and achieved $>90 \%$ transfection efficiency using the Lipofectamine 2000 reagent (Invitrogen, Carlsbad, CA, USA). To transfect PBEF stealth siRNA into human A549 cells, cells were seeded for $24 \mathrm{~h}$ in the regular growth medium (without antibiotics) so that they would be $80-$ $90 \%$ confluent at the time of transfection. For each trans- 
fection in 24-well plates, 50 pmol PBEF stealth siRNA was diluted in $50 \mu \mathrm{l}$ Opti-MEM I without serum and gently mixed with $1 \mu \mathrm{l}$ Lipofectamine 2000 diluted in the $50 \mu \mathrm{l}$ Opti-MEM I (Invitrogen, Cat. 31985-062). After incubation for $15 \mathrm{~min}$ at room temperature, PBEF stealth siRNA and Lipofectamine 2000 complexes were added to each well. Cell culture plates were gently mixed by rocking back and forth. The amount of PBEF stealth siRNA and Lipofectamine 2000 were adjusted according to the different sizes of cell culture plates. Transfected cells were further incubated at $37^{\circ} \mathrm{C}$ for $24-48 \mathrm{~h}$ until treatment with TNFa before intended assays were carried out. Primary human lung small airway epithelial cells were similarly transfected. Transfection of PBEF siRNA into HPAEC was performed as previously described by Ye et al [7].

\section{Preparation and expression of the PBEF-overexpressing construct pCAGGS-hPBEF}

A human PBEF (hPBEF) coding cDNA was amplified from A549 cell total RNA by RT-PCR using the following primer pair designed according to the reference human PBEF mRNA sequence (NM_005746.2): forward primer, 5'TTAGAATTCGCCACCATGCCTGCGGCAGAAGCC-3' and reverse primer, 5'-TTAGAATTCTTAATGGTGATGGTGATGATGCAAATGATGTGCTGCTTCCAGTTC-3'. The regular bold letters indicate the optimized Kozac sequence. The bold italic letter part is His tag sequence. The underlined sequences are EcoRI adaptors. The amplified human PBEF cDNA was digested with EcoRI and subcloned into the unique EcoRI site of pCAGGS vector, which was provided by Dr. Deyu Fang (Department of Molecular Microbiology and Immunology, University of Missouri-Columbia). After the cloning, pCAGGS-hPBEF was sequence-verified. In this construct, human PBEF expression was driven by a chicken beta-actin/rabbit beta-globin hybrid promoter (AG) with an enhancer from the human cytomegalovirus immediate early promoter (CMV-IE). Overexpression of PBEF in A549 cells and HPAEC was carried out by a transient transfection of pCAGGS-hPBEF. Briefly, one day before transfection, A549 cells or HPAEC were plated in 6well plate at $5 \times 10^{5}$ cells/well in $2 \mathrm{ml}$ of growth medium without antibiotics. On the day of transfection, cells were at $95 \%$ confluence. For each well, $4 \mu$ g plasmid DNA was transfected using Lipofectamine 2000 according to the suppliers' instruction. Cell medium and cell lysate proteins were harvested at 48,72 and 96 hours after the transfection for western blotting analyses of IL-8, PBEF and $\beta$ - actin protein levels in A549 cells. pCAGGS-hPBEF or pCAGGS transfected HPAEC were used only for the assessment of cell permeability.

\section{Isolation of RNA and RT-PCR analysis}

Total RNA was isolated from A549 cells with TRIZOL solution (Cat. No. 15596-018, Invitrogen, Carlsbad, CA, USA) according to the supplier's instructions. RT-PCR was performed using Invitrogen RNA PCR kit (Superscript III, 18080-044) with the following procedures: $1 \mu \mathrm{g}$ total RNA was reverse transcribed with random primer at $50^{\circ} \mathrm{C}$ for $1 \mathrm{~h}$ followed by $70^{\circ} \mathrm{C}$ for $15 \mathrm{~min}$ and $4^{\circ} \mathrm{C}$ for $5 \mathrm{~min}$ in a $20 \mu \mathrm{l}$ reaction volume. Each PCR reaction from the cDNA template ( $2 \mu \mathrm{l}$ RT product) was performed using gene specific primers (Table 1 ) at $94^{\circ} \mathrm{C}$ for $3 \mathrm{~min}$, then 32 cycles at $94^{\circ} \mathrm{C}$ for $1 \mathrm{~min}, 55^{\circ} \mathrm{C}$ for $1 \mathrm{~min}$ and $72^{\circ} \mathrm{C}$ for 1 min, followed by $72^{\circ} \mathrm{C}$ for $7 \mathrm{~min}$ for the final extension. $\beta$-actin was used as a house-keeping gene control. PCR products were separated on a $1.5 \%$ agarose gel and stained by Ethidium Bromide $(0.5 \mu \mathrm{g} / \mathrm{ml})$. The band image was acquired using an Alpha Imager and analyzed by the AlphaEase ${ }^{\mathrm{TM}}$ Stand Alone Software (Alpha Innotech Corp., San leandro, CA, USA).

\section{Western blotting}

Western blot analysis was performed following the protocol of Bio-Rad Company. Briefly, after washing with PBS, cells were lysed with $500 \mu \mathrm{l}$ of cell lysis buffer containing $10 \mathrm{mM}$ Tris (pH 7.4), $1 \%$ Triton X-100, $0.5 \%$ Nonidet P40, $150 \mathrm{mM} \mathrm{NaCl}, 1 \mathrm{mM}$ EDTA, $0.2 \mathrm{mM}$ EGTA, $0.2 \mathrm{mM}$ vanadate, $0.2 \mathrm{mM}$ PMSF, and $0.5 \%$ protease inhibitor cocktail. Total cell lysates were cleared by centrifugation and boiled with the same amount of $4 \times$ SDS sample buffer for $5 \mathrm{~min}$. Total protein of cell lysates was quantified using the BCA Protein Assay Kit (Pierce Biotechnology, Inc., Rockford, IL, USA). An equal amount of total protein from each sample was then subjected to $16.5 \%$ Tris/tricine polyacrylamide gel electrophoresis. The separated proteins were transferred to PVDF membranes by electrotransfer. The blots were subsequently blocked with $5 \%$ bovine serum albumin in PBS containing $0.1 \%$ Tween 20 (TBS-T) at room temperature for $1 \mathrm{~h}$ and then incubated at $4{ }^{\circ} \mathrm{C}$ overnight with primary antibodies of interest. After washing three times for 10 min with TBS-T, the membrane was incubated with horseradish-peroxidaselinked secondary antibodies of interest at room temperature for $1 \mathrm{~h}$. The blots were then visualized with the ECL

Table I: Primers and products sizes

\begin{tabular}{|c|c|c|c|c|}
\hline Products & 5' Primers & 3' Primers & Size (bp) & Accession No. \\
\hline IL-8 & ATGACTTCCAAGCTGGCCGT & ССТСТТСАААААСТТСТССАСАСС & 297 & NM_000584 \\
\hline PBEF & AAGCTTTTTAGGGCCCTTTG & AGGCCATGTTTTATTTGCTGACAAA & 319 & NM_005746 \\
\hline$\beta$-actin & CAAACATGATCTGGGTCATCTTCTC & GCTCGTCGTCGACAACGGCTC & 487 & NM_00II0I \\
\hline
\end{tabular}


Western blot detection system (Cat. No. RPN2106, Amersham Bosciences, Buckinghamshire, UK). The same membrane was re-probed with an anti-human $\beta$-actin antibody. $\beta$-actin was used as an internal control. Band density on Western blot images was used as a measure of assayed protein level. The band image was acquired using an Alpha Imager and analyzed by the AlphaEase ${ }^{\mathrm{TM}}$ Stand Alone Software.

\section{In Vitro Cell Permeability Assay}

In Vitro Cell Permeability Assay was carried out according to the protocol of the CHEMICON in vitro Vascular Permeability Assay kit (Cat. No. ECM640, Millipore, Billerica, MA, USA). Briefly, cells were seeded to the culture inserts of permeability chambers $\left(1.0 \times 10^{6}\right.$ cells $\left./ \mathrm{ml}\right)$ that were coated with collagen. Then, cells were incubated in $37^{\circ} \mathrm{C}$ and 5\% until a monolayer was formed. After TNFa (Cat. No. 636-R1, R\&D systems, Minneapolis, MN, USA) was added, cells were incubated for another 18 hours at $37^{\circ} \mathrm{C}$ and $5 \% \mathrm{CO}_{2}$ in the tissue culture incubator. Finally, 150 $\mu \mathrm{l}$ of FITC-Dextran was added to each insert for $5 \mathrm{~min}$ at room temperature, and then $100 \mu \mathrm{l}$ of the solution in the bottom chamber was transferred to a 96-well plate. The plate was read in a TriStar Multimode Reader (LB 941, Berthold Technologies GnbH \& Co. KG, Bad Wildbad, Germany) at wavelengths of 485 and $530 \mathrm{~nm}$. Reagent control wells were treated with basal medium and growth medium only. Blank inserts without cells plated were also included as controls.

\section{Statistical analysis}

Statistical analyses were performed using SigmaStat (ver 3.5, Systat Software, Inc., San Jose, CA, USA). Results are expressed as mean \pm standard deviation (SD) of four samples from at least two independent experiments. Stimulated samples were compared with controls by unpaired Student's t test. $\mathrm{P}<0.05$ was considered statistically significant.

\section{Results}

Dose-response and time-course of TNF $\alpha$ induced IL-8 protein expression in $\mathbf{A 5 4 9}$ cells

In order to examine the role of PBEF in human pulmonary alveolar epithelial cell inflammation, we began by quantifying TNF $\alpha$ induced IL-8 protein expression within A549 cells. We first determined the dose-response and timecourse of TNF $\alpha$ induced IL-8 protein expression in A549 cells in our experimental conditions. The results (Figure 1, panel A) demonstrate that TNF $\alpha$ treatment for $24 \mathrm{~h}$ significantly induced IL- 8 secretion in A549 cells in a dosedependent manner up to the highest tested concentration of TNF $\alpha$ (25 ng/ml). Within the cell lysate, IL-8 level was also increased with TNF $\alpha$ treatment but was not dosedependent within the tested dose range. Secreted IL-8 levels was also significantly increased in a time-dependent manner after TNF $\alpha(15 \mathrm{ng} / \mathrm{ml})$ treatment compared with control group (Figure 1, panel B), especially at 6, 18, and 24 h time points. Again, cell lysate IL-8 levels were increased with treatment but not in a time dependent manner. These data indicate that TNF $\alpha$ significantly increased IL-8 secretion in dose-dependent and timedependent manners in A549 cells in our experimental conditions. The $24 \mathrm{~h}$ time point and $15 \mathrm{ng} / \mathrm{ml}$ of TNF $\alpha$ dosage were selected for subsequent experiments.

\section{Dose-response and time-course of TNF $\alpha$ induced PBEF protein expression in $\mathbf{A 5 4 9}$ cells}

After a pilot experiment provided evidence that PBEF expression could be induced by TNF $\alpha$ treatment in A549 cells (data not shown), we sought to determine the doseresponse and time-course to optimize the experimental conditions of TNF $\alpha$ induced PBEF expression in A549 cells. In this dose-response experiment (Figure 2, panel A), our results show that secreted PBEF level was increased in a dose-dependent manner and cell lysate PBEF expression was significantly increased compared to control at all dose treatments of TNF $\alpha$ tested $[15 \mathrm{ng} / \mathrm{ml} \mathrm{TNF} \alpha$ treatment vs. control: $1.17 \pm 0.02$ vs. $0.9 \pm 0.005, \mathrm{n}=4, \mathrm{p}<0.05]$ ] In the time-course experiment (Figure 2, panel B), secreted and intracellular PBEF protein expression continued to increase over the $24 \mathrm{~h}$ of TNF $\alpha$ treatment [TNF $\alpha$ treatment vs. control at $24 \mathrm{~h}: 1.56 \pm 0.04$ vs. $0.837 \pm 0.03, \mathrm{n}=4, \mathrm{p}<$ $0.01]$. The dose-response and time-course of TNF $\alpha$ mediated PBEF expression in A549 cells are similar to those of IL-8.

\section{TNF $\alpha$ induction of IL-8 and PBEF expression at their mRNA levels in A549 cells}

To investigate whether TNF $\alpha$ augments IL-8 and PBEF expression at their mRNA levels in A549 cells, we performed a semi-quantitative RT-PCR analysis of IL- 8 and PBEF mRNA levels in TNFa induced A549 cells. As presented in Figure 3, IL-8 and PBEF mRNA levels in TNF $\alpha$ treated A549 cells were significantly increased compared to the control groups (IL-8 mRNA expression: $0.89 \pm 0.04$ vs. $0.42 \pm 0.05, \mathrm{n}=4, \mathrm{p}<0.01$; PBEF mRNA expression: $0.5 \pm 0.04$ vs. $0.37 \pm 0.025, \mathrm{n}=4, \mathrm{p}<0.05$; respectively)

\section{Knockdown of PBEF protein and mRNA expression by PBEF stealth siRNA in A549 cells}

We first performed a pilot experiment to demonstrate that PBEF siRNA could in fact knock down PBEF expression in A549 cells before determining the optimal time course and dose response of PBEF stealth siRNA for the inhibition of PBEF protein expression in A549 cells (data not shown). The $48 \mathrm{~h}$ time point and $50 \mathrm{~nm}$ dosage were selected for the intended experimentation. In the baseline condition without the TNF $\alpha$ treatment (Figure 4, Panels A and B), PBEF siRNA significantly knocked down PBEF protein expression in A549 cells [siRNA vs. control: 1135 

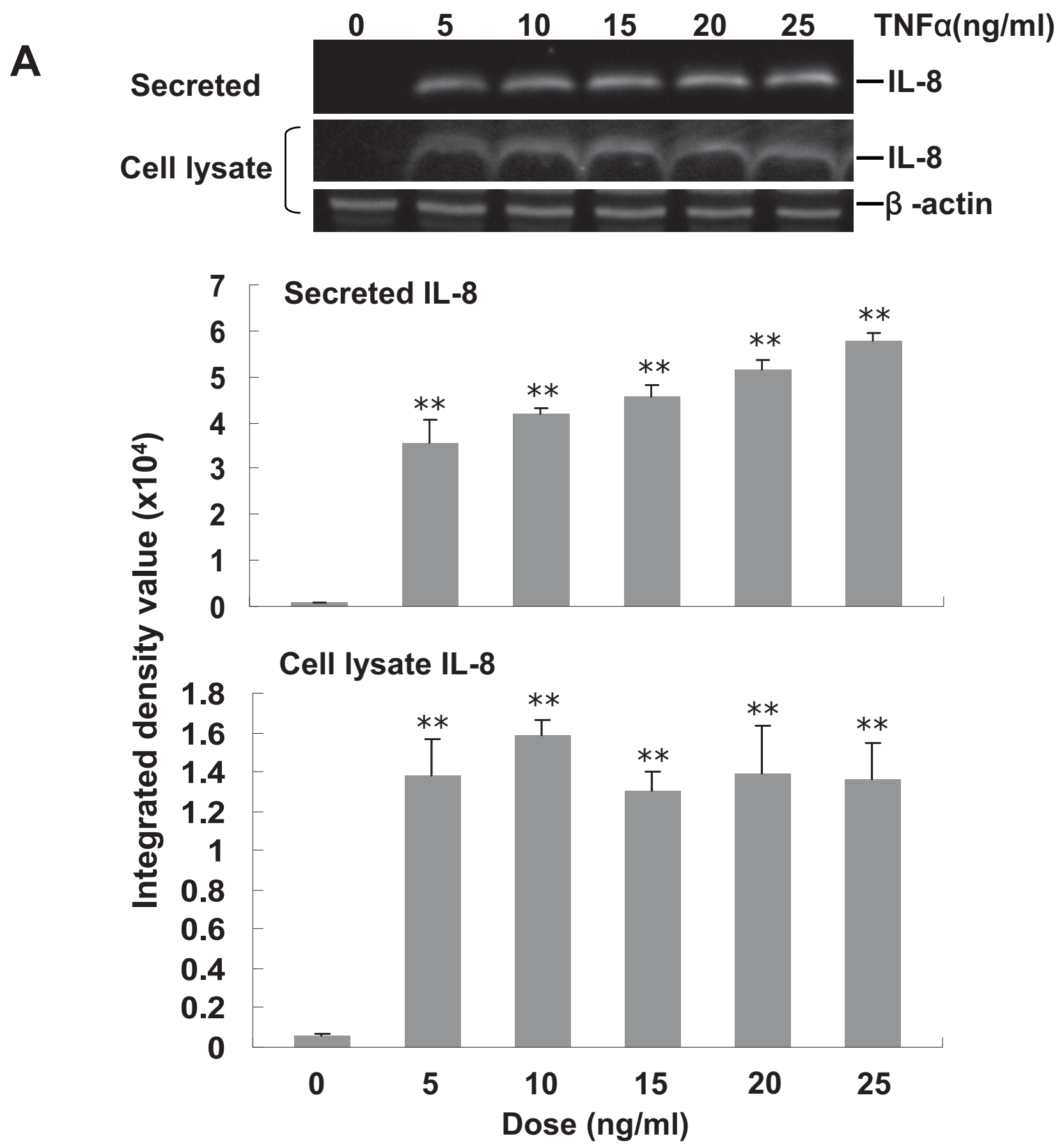

Figure I (see legend on next page) 
Figure I (see previous page)

Dose-response and time-course of TNF $\alpha$-induced IL-8 protein expression in A549 cells. A. Dose-response. The top panel illustrates a typical western blotting image of IL-8 and $\beta$-actin protein detections. After starving for serum overnight, A549 cells were stimulated with different doses of TNF $\alpha$ as indicated for 24 hours. Equal amount of total protein from each sample was separated by $16.5 \%$ SDS-PAGE and immunodetected by the western blotting using anti-human IL-8 or $\beta$-actin antibodies. Middle panel-Quantitation of secreted IL-8 level by densitometric analysis. Results from each group are presented as mean \pm SD of 4 samples from two separate experiments. Bottom panel-Quantitation of cell lysate IL-8 level by densitometric analysis. ${ }^{* *} \mathrm{p}<0.0 \mathrm{I}$ vs. control $(0 \mathrm{ng} . \mathrm{ml}$ TNF $\alpha)$. B. Time-course. Top panel-Representative western blotting image of IL-8 and $\beta$-actin protein detections. After starving for serum overnight, A549 cells were stimulated with TNF $\alpha$ (I5 ng/ml) for different time (h) as indicated. Middle panel-Quantitation of secreted IL-8 protein level by densitometric analysis. Bottom panel-Quantitation of cell lysate IL-8 protein level by densitometric analysis. ${ }^{*} \mathrm{p}<0.05$ and $*^{*} \mathrm{p}<0.0 \mathrm{I}$ vs 0 dosage of TNF $\alpha$ or $0 \mathrm{~h}$ control.

\pm 33 vs. $3253 \pm 624, \mathrm{n}=4, \mathrm{p}<0.01]$. Scrambled RNA (scRNA) and reagent alone had no effect on PBEF protein expression. PBEF-specific siRNA had no effect on the protein expression level of $\beta$-actin, a house-keeping gene serving as a control. In the $+\mathrm{TNF} \alpha$ treatment group (Figure 4, Panels A and B), PBEF protein level in the scRNA group had no significant change (scRNA vs. control: $7246 \pm 856$ vs. $6440 \pm 889, \mathrm{n}=4$, NS), while PBEF protein level in the siRNA group was significantly lower than in the control (siRNA vs. control: $1926 \pm 415$ vs. $7246 \pm 856, \mathrm{n}=4, \mathrm{p}<$ $0.01)$. Figure 4, panels $\mathrm{C}$ and $\mathrm{D}$, illustrates the expected effect of PBEF siRNA on significantly inhibiting PBEF mRNA expression in both the baseline and treated groups. These results indicate that PBEF-specific siRNA can significantly reduce both PBEF protein and mRNA production in both baseline and TNF $\alpha$ activated A549 cells.

PBEF silencing attenuated TNF $\alpha$-induced increases in IL-8 secretion and IL-8 mRNA expression within A549 cells

Based on an efficient knock down of PBEF in A549 cells with PBEF siRNA, we next evaluated the effect of PBEF knockdown on the TNF $\alpha$-induced increases in IL- 8 secretion and IL- 8 mRNA level from A549 cells. In Figure 5 (panels A and B) PBEF silencing significantly decreased IL8 secretion from A549 cells in TNFa-stimulated conditions compared to the control group (siRNA vs. control: $2807.69 \pm 161.2$ vs. $9178.58 \pm 512.64, \mathrm{n}=4, \mathrm{p}<0.01)$, while secreted IL- 8 level in the scRNA group had a small and statistically insignificant change relative to the control group (scRNA vs. control: $8808.37 \pm 400.52$ vs. $9178.58 \pm$ $512.64, \mathrm{n}=4, \mathrm{NS}$ ). Further, Figure 5 (panels C and D) demonstrates that PBEF silencing decreased IL- 8 mRNA expression levels in the baseline (-TNFa) group (siRNA vs. control: $886.17 \pm 190$ vs. $3718.27 \pm 360, \mathrm{n}=4, \mathrm{p}<0.01)$ as well as the treatment $(+\mathrm{TNF} \alpha)$ group (siRNA vs. control: $2128.78 \pm 96$ vs. $3255.42 \pm 107, \mathrm{n}=4, \mathrm{p}<0.05)$. These results indicate that PBEF is involved in IL-8 expression and secretion under both baseline and TNF $\alpha$-stimulated conditions within the A549 cells.
PBEF silencing attenuated TNF $\alpha$-induced increases in IL-8 secretion and PBEF protein expression in lung primary small airway epithelial cells

To further confirm the above results, we also investigated PBEF effects on TNF $\alpha$-induced IL- 8 secretion in primary human lung small airway epithelial cells. In Figure 5 (panels $\mathrm{E}$ and F), PBEF silencing is shown to decrease IL-8 secretion in TNF $\alpha$-stimulated conditions (siRNA vs. control: $10609.50 \pm 4086.65$ vs. $28801.42 \pm 1235.48, \mathrm{n}=4$, $\mathrm{p}<0.01)$. In contrast, scRNA demonstrated no difference from control. These results indicate that PBEF is also involved in IL-8 expression and secretion in TNF $\alpha$ induced conditions in primary human lung small airway epithelial cells.

\section{PBEF over-expression augmented IL-8 secretion from A549 cells}

Since PBEF silencing could decrease TNF $\alpha$-induced IL- 8 secretion from A549 cells, the next experiments evaluated whether PBEF over-expression would augment IL-8 secretion from A549 cells. Similarly treated non-transfected A549 cells served as the control. In Figure 6 (panels A and B), the over-expression of PBEF in A549 cells transiently transfected with pCAGGS-hPBEF was achieved in both the secreted PBEF levels (transfected vs. control: $29712.81 \pm$ 16259.85 vs. $948.75 \pm 136.7, \mathrm{n}=4, \mathrm{p}<0.01$ ) and in cell lysate PBEF levels (transfected vs. control: $70666.3 \pm$ 22445.3 vs. $13519.15 \pm 5745.44, \mathrm{n}=4, \mathrm{p}<0.01)$. PBEF over-expression significantly increased IL-8 secretion from A549 cells compared to control group (transfected vs. control: $111548.4 \pm 84104.5$ vs. $1034 \pm 212.5, \mathrm{n}=4, \mathrm{p}<$ $0.01)$. These findings suggest that PBEF has a direct effect on IL- 8 secretion from A549 cells. Further, Figure 6 (panels $\mathrm{C}$ and $\mathrm{D}$ ) demonstrates that PBEF over-expression also significantly augmented TNF $\alpha$-induced IL-8 secretion from A549 cells compared to control group (transfected vs. control: $604423.1 \pm 82477.6$ vs. $350227.4 \pm 19794.1$ ) and IL-8 production in cell lysate in A549 cells compared to control group (transfected vs. control: $420519.4 \pm$ 49539.8 vs. $224406.9 \pm 45849.1$ ). Those result further confirmed that PBEF has a very important role in TNF $\alpha$ induced IL-8 secretion in A549 cells. 


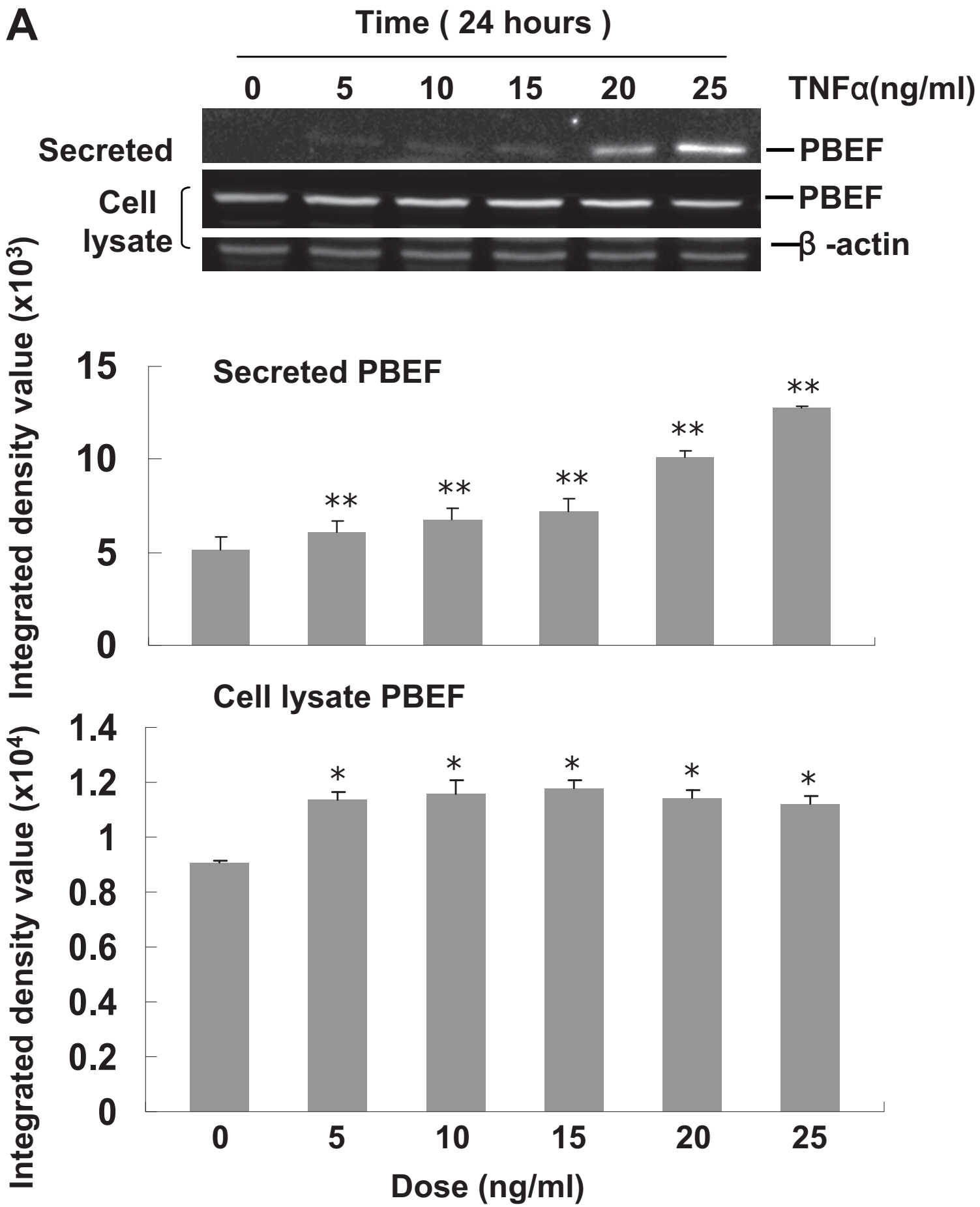

Figure 2 (see legend on next page) 
Figure 2 (see previous page)

Dose-response and time-course of TNF $\alpha$ induced PBEF protein expression in A549 cells. A. Dose-response. The top panel is a typical western blotting image of PBEF and $\beta$-actin protein detections. After starving for serum overnight, A549 cells were stimulated with different doses of TNF $\alpha$, as indicated, for 24 hours. Equal amount of total cell lysate protein from each sample was separated by $10 \%$ SDS-PAGE and immunodetected by the western blotting using anti-human PBEF or $\beta$-actin antibodies. Middle panel-Quantitation of secreted PBEF level by densitometric analysis. Results from each group are presented as mean \pm SD of 4 samples from two separate experiments. The bottom panel is the quantitation of cell lysate PBEF protein level by densitometric analysis. $B$. Time-course. Top panel-Representative western blotting image of PBEF and $\beta$-actin protein detections. After starving for serum overnight, A549 cells were stimulated with TNF $\alpha$ (I5 ng/ml) for different time (h) as indicated. Lower panel-Quantitation of cell lysate PBEF protein level by densitometric analysis. $*_{p}<0.05$ and $*^{*} p<0.01$ vs 0 dosage of TNF $\alpha$ or $0 \mathrm{~h}$ control.

\section{PBEF expression affected cell permeability in A549 cells} and human pulmonary artery endothelial cells (HPAEC) To assess whether PBEF expression affected lung alveolar epithelial cell and HPAEC permeability, we performed in vitro monolayer cell permeability assays in A549 cells and HPAEC transfected with PBEF stealth siRNA or pCAGGShPBEF in the presence and absence of TNF $\alpha$ treatment. Controls were either scRNA or reagent vehicle without the vector, respectively. In Figure 7A, PBEF siRNA significantly decreased TNF $\alpha$-induced permeability in A549 cells compared to the TNF $\alpha$ treated controls (siRNA vs. control: $15476.09 \pm 577.35$ vs. $27065 \pm 563.04, \mathrm{n}=4, \mathrm{p}<0.01)$ Scrambled RNA had no effect on the TNFa-induced cell permeability in A549 cells. Under baseline (-TNF $\alpha$ ) conditions, no differences in cell permeability were detected. These results indicate PBEF siRNA significantly attenuated the TNF $\alpha$-induced barrier-disruption within the epithelial cells. To validate our observation in A549 cells, we performed the same experiment in a primary HPAEC. As displayed in Figure 7C, similar observations were obtained in HPAEC, whose cell permeability level in the PBEF siRNA group was significantly decreased compared to the TNF $\alpha$ alone treatment $(13325 \pm 1527.2$ vs. $30850 \pm 937.5$ relative fluorescence units, $\left.\mathrm{n}=4,{ }^{*} * \mathrm{P}<0.01\right)$. Scrambled RNA had no effect on the TNF $\alpha$ induced cell permeability in both A549 cells and HPAEC (Figure 7C). In Figure 7B, PBEF overexpression significantly promoted TNF $\alpha$ induced A549 cell permeability level in the pCAGGShPBEF transfected group compared to the control groups (overexpression vs. control: 29156.09 \pm 113.57 vs. $18570.4 \pm 84.85, \mathrm{n}=4, \mathrm{p}<0.01)$. Similar observations were obtained in HPAEC cells (Figure 7D), whose cell permeability level in the PBEF overexpression group is significantly increased compared to the TNF $\alpha$ alone treatment $(36955 \pm 306.4$ vs. $26331 \pm 300.69$ relative fluorescence units, $\left.\mathrm{n}=4,{ }^{*} \mathrm{P}<0.01\right)$. Scrambled RNA had no effect on the TNF $\alpha$ induced cell permeability in both A549 and HPAEC cells (Figure 7A and 7C). Even under baseline (TNFa) conditions, overexpressing PBEF significantly increased cell permeability in A549 cells (over-expression vs. control: $12506.14 \pm 141.42$ vs. $2537.4 \pm 154.27, \mathrm{n}=4$, $\mathrm{p}<0.01)$ and HPAEC $(22336.45 \pm 70.71$ vs. $13675.4 \pm$
117.85 relative fluorescence units, $\mathrm{n}=4, * \mathrm{P}<0.05)$. These results indicate that overexpression of PBEF augmented in vitro lung epithelial cell permeability under both the baseline and TNF $\alpha$-induced conditions.

\section{Discussion}

Our findings demonstrate that the modulation of PBEF expression resulted in parallel changes in TNF $\alpha$-mediated IL-8 production and secretion as well as alveolar epithelial cell permeability. These results provide new insight into the role of PBEF in the inflammatory pathways and functional abnormalities associated with ALI.

There is considerable experimental and clinical evidence that pro-inflammatory cytokines play a major role in the pathogenesis of ALI/ARDS from inflammatory causes, such as sepsis, pneumonia, aspiration, and shock [8], as well as from mechanical stress [9-11]. The landmark ARDSnet clinical trial found that a lung-protective ventilatory strategy reduces mortality by $22 \%$ in patients with ALI, a result that in part may be ascribed to the marked reduction in the concentration of pro-inflammatory cytokines released into the airspaces of the injured lung [12,8]. TNF $\alpha$ and IL- 8 are among important early mediators of ALI [4]. It has been shown that $\mathrm{TNF} \alpha$ is present in increased amounts in the bronchoalveolar lavage fluid (BALF) of patients with ARDS [13], in the serum during the onset of sepsis-induced lung injury [14], and acutely increases in both serum and BALF when changing from a lung protective to non-protective ventilation strategy [9]. Increasing TNF $\alpha$ biological activity has been demonstrated over the first week of ARDS and there are direct relationships between the molar ratio of $\mathrm{TNF} \alpha /$ soluble TNF-receptor in the BALF and severity of ALI (lung compliance and severity of hypoxemia) [13]. The role of TNF $\alpha$ in pulmonary pathophysiology has been well studied, and includes induction of cellular inflammatory reactions, enhancement of oxidative stress, and increased expression of various proinflammatory molecules [15].

Among the TNF $\alpha$ induced pro-inflammatory cytokines, IL- 8 is regarded as one of the most important mediators in 


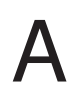

\section{control TNF a}
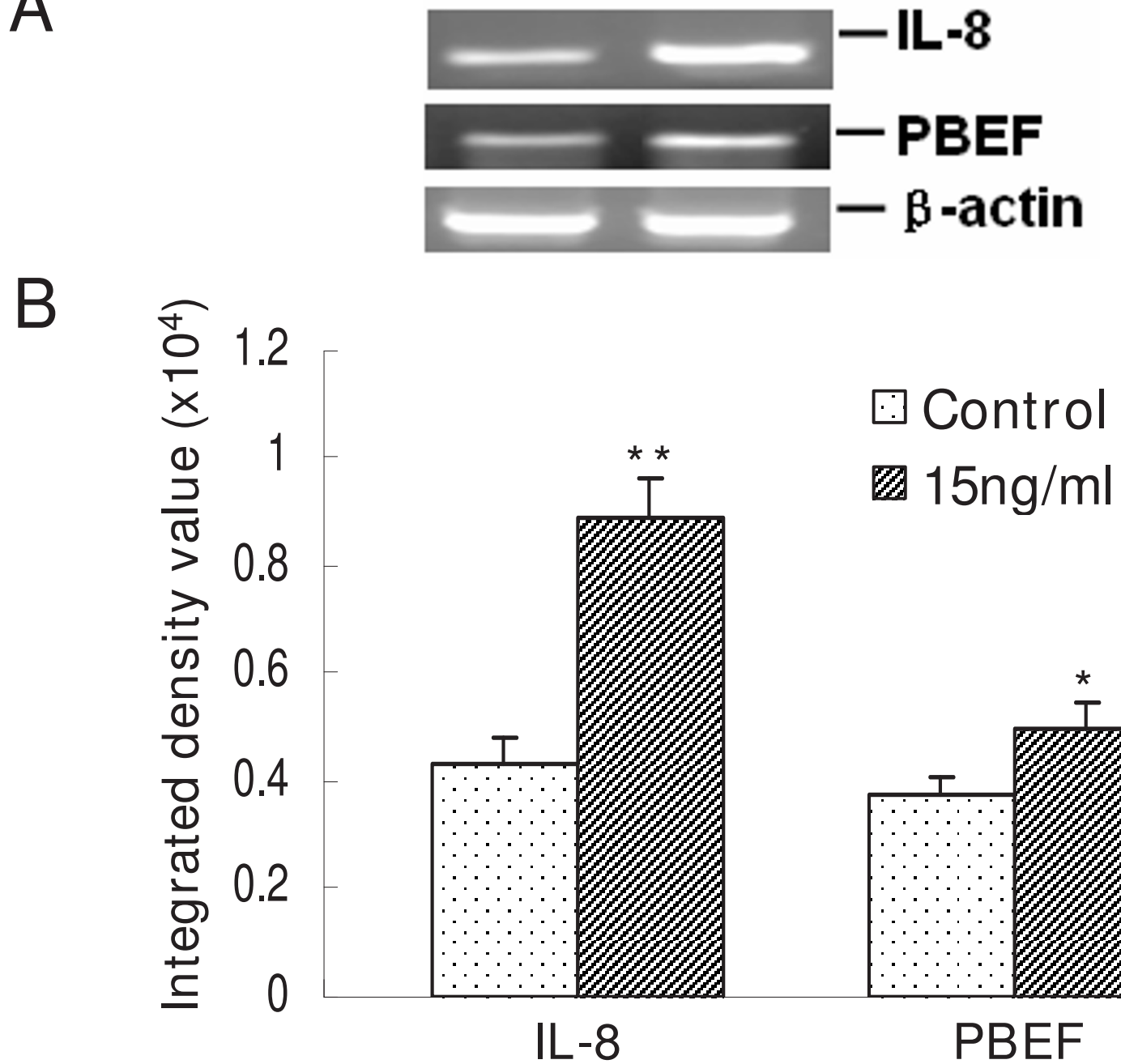

Figure 3

Effect of TNF $\alpha$ treatment on the mRNA expression of IL-8 and PBEF in A549 cells. A. A representative gel image of IL-8, PBEF and $\beta$-actin mRNA detections. After starving for serum overnight, A549 cells were stimulated with TNF $\alpha$ (I5 ng/ $\mathrm{ml}$ ) for $4 \mathrm{~h}$. Total cell RNA was reverse-transcribed, amplified by PCR using the gene specific primers (Table I), separated by I.5\% agarose electrophoresis, and visualized with ethidium bromide. B. Quantitation of IL-8 and PBEF mRNA levels by densitometric analysis. Results from each group are presented as mean \pm SD of 4 samples from two separate experiments. ${ }^{*} p<0.05$ and ${ }^{* *} \mathrm{p}<0.0 \mathrm{I}$ vs 0 dosage of TNF $\alpha$ or control.

the pathogenesis of ARDS. In BALF, IL-8 levels were significantly increased in patients with ARDS and correlated with the development of ARDS in at-risk patients [16,17]. IL- 8 has been identified as one of biomarkers of ALI/ ARDS mortality [18]. In fact, IL- 8 was first purified and molecularly cloned as a neutrophil chemotactic factor from lipopolysaccharide-stimulated human mononuclear cell supernatants [19]. Since then, studies of models of acute inflammation have established IL- 8 as a key media- tor in neutrophil mediated acute inflammation [20]. In acid aspiration- and endotoxemia-induced ARDS in rabbits, IL- 8 is produced in the lungs $[21,22]$. In both models, the abrogation of IL- 8 activity reduces neutrophil infiltration as well as tissue damage. It was demonstrated that TNF $\alpha$ mediated IL-8 production can suppress neutrophil apoptosis [23] and thus potentially prolong neutrophil migration into the lungs and damage to lung tissues, including alveolar epithelial barrier function [24]. 

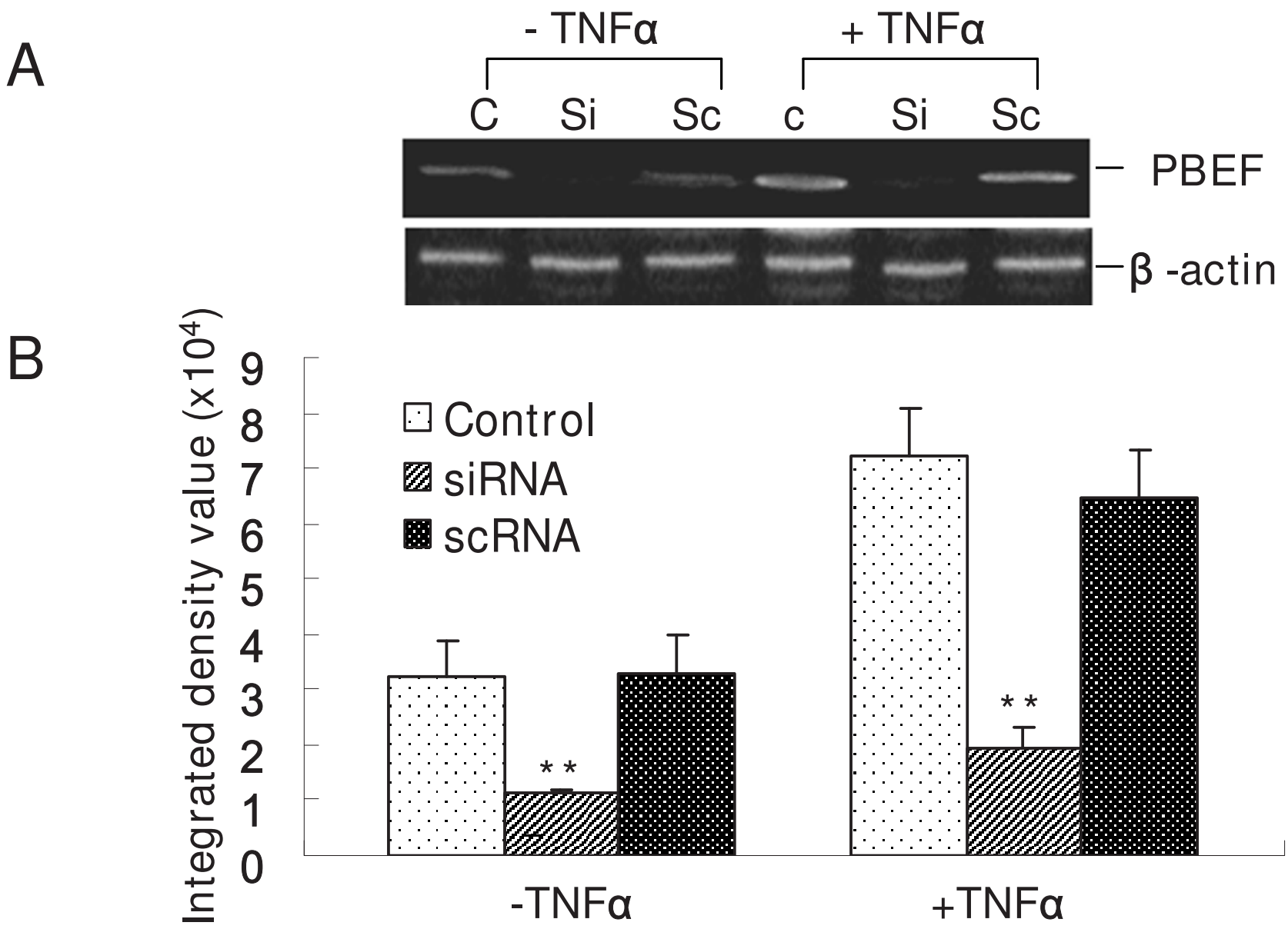

Figure 4

PBEF stealth siRNA-mediated silencing of PBEF protein and mRNA expression in A549 cells. A. Representative western blotting image of PBEF protein detections. After starving for serum overnight, A549 cells were transfected with the control (C), scrambled siRNA (Sc), or 50 nmolar PBEF stealth siRNA (Si) for $48 \mathrm{~h}$ before treatment without or with TNF $\alpha$ (I 5 $\mathrm{ng} / \mathrm{ml}$ ) for 24 hours. Cell lysate PBEF and $\beta$-actin protein were immunodetected as described. B. Quantitation of PBEF protein levels by densitometric analysis. A549 Cell lysate PBEF protein levels in various treatments were quantified by densitometric analysis. **p $<0.01$. C. A representative RT-PCR gel image of PBEF and $\beta$-actin mRNA detections. A549 cells were grown and transfected with the PBEF siRNA and other controls as described above and then treated without or with TNF $\alpha$ (I5 ng/ml) for 4 hours. Total cell RNA was reverse-transcribed, amplified by PCR using gene specific primers (Table I), separated by I.5\% agarose electrophoresis and visualized with ethidium bromide. D. Quantification of PBEF mRNA level by densitometric analysis. $* * \mathrm{p}<0.01$ vs. control.

Our data in this study indicate that TNF $\alpha$ significantly induces PBEF expression at both the mRNA and protein levels in A549 cells (Figures 2, 3, 4, 5), suggesting that PBEF may be an intermediate target of TNF $\alpha$ involved in the inflammatory process during the pathogenesis of ALI. The knockdown of PBEF expression by PBEF siRNA significantly blunted TNF $\alpha$-stimulated IL- 8 secretion and its production in A549 cells (Figures 6, 7), and PBEF-overexpression augmented IL-8 secretion from A549 cell (Figure 7 ). These results support the concept that PBEF may be an inflammatory signal transducer of TNF $\alpha$ or other inflam- matory stimuli to regulate the synthesis of IL- 8 or other inflammatory cytokines. These conclusions can be corroborated by evidence in non-lung tissue studies. PBEF silencing has been shown to prevent the suppression of neutrophil apoptosis caused by TNF $\alpha$, IL-8 and other mediators [25]. In addition, PBEF gene expression is upregulated in severely infected fetal membranes [26]. Inflammatory stimuli in fetal membranes inducing NF- $\kappa$ B and AP-1 have been shown to up-regulate PBEF [27]. The recombinant human PBEF treatment of amnion-like epithelial cells and fetal membrane explants significantly 


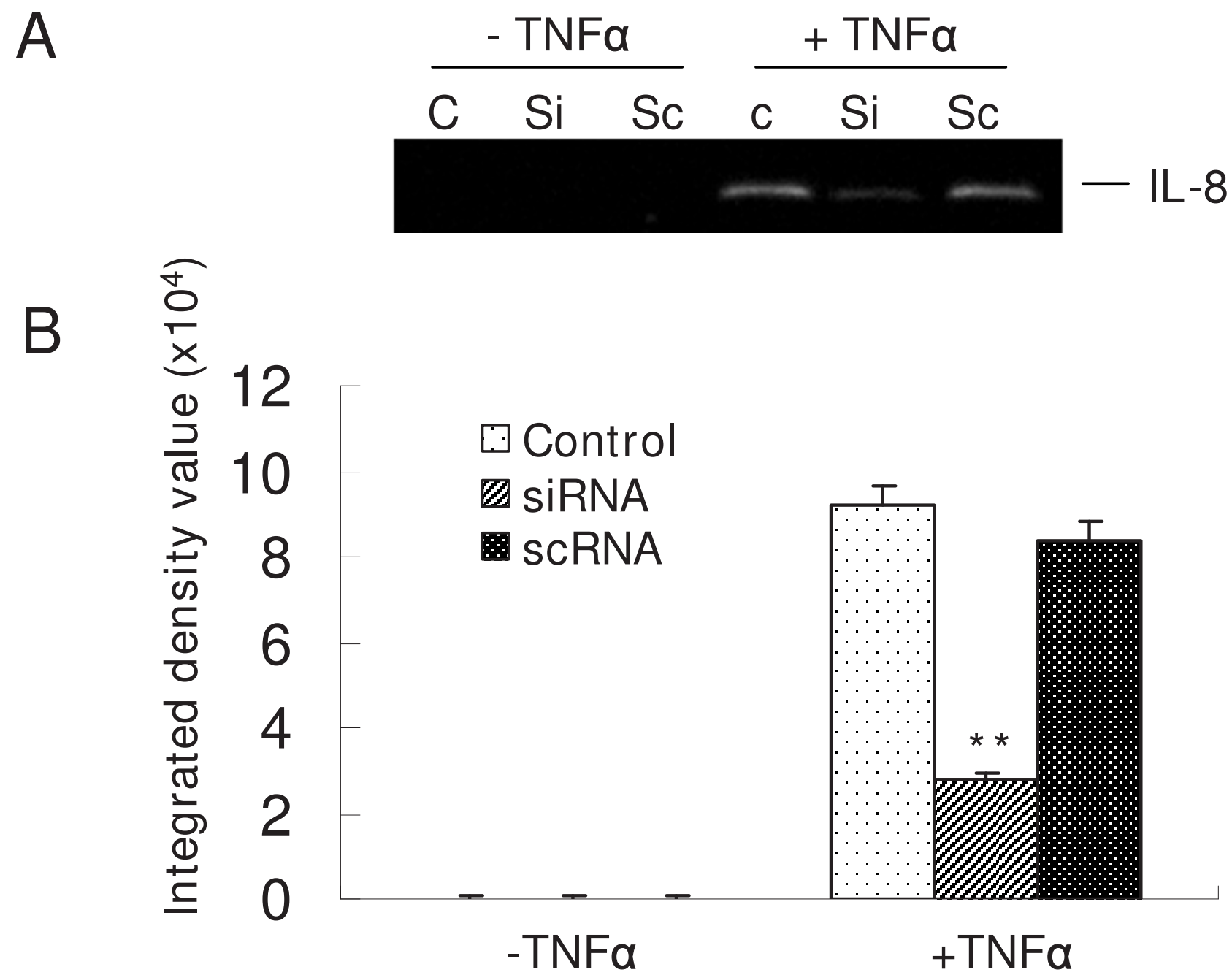

Figure 5

Effects of PBEF knock down on IL-8 protein \& mRNA expression in A549 cells (A-D) and in lung primary small airway epithelial cells (E-F). A. Representative western blotting image of secreted IL-8 protein detections. After starving for serum overnight, $A 549$ cells were transfected with the vehicle control (C), scrambled siRNA (Sc), or PBEF stealth siRNA (Si) for $48 \mathrm{~h}$ before treatment without or with TNF $\alpha(I 5 \mathrm{ng} / \mathrm{ml})$ for 24 hours. B. Quantitation of secreted IL-8 protein levels by densitometric analysis. ${ }^{*} \mathrm{p}<0.0 \mathrm{I}$ vs. control. C. Representative RT-PCR gel image of IL-8 and $\beta$-actin mRNA detections. A549 cells were grown and transfected with the PBEF siRNA and other controls as described above before treatment without or with TNF $\alpha$ (I5 ng/ml) for 4 hours. Total cell RNA was reverse-transcribed, amplified by PCR using gene specific primers (Table I), separated by I.5\% agarose electrophoresis and visualized with ethidium bromide. D. Quantitation of IL-8 mRNA level by densitometric analysis. ${ }^{*}$ p $<0.01$ vs. control. E. Representative western blotting images of cell lysate PBEF and secreted IL-8 protein detections. Lung primary small airway epithelial cells were transfected with control (C), PBEF stealth siRNA (Si), or scrambled RNA (Sc) for $48 \mathrm{~h}$ before treatment without or with TNF $\alpha$ (I0 ng/ml) for I2 hours. PBEF in cell lysate and secreted IL-8 protein were immunodetected as described in Figures I and 2. F. Quantitation of IL-8 and PBEF protein levels by densitometric analysis. ${ }^{*} \mathrm{p}<0.0 \mathrm{l}$ vs. control.

increased IL-6 and IL-8 expression [28]. Considered together, PBEF could play a critical role as an inflammatory cytokine during the pathogenesis of ALI.
Both endothelial and epithelial injuries were observed in earlier ultrastructural studies of the lung in patients dying with ALI secondary to sepsis $[29,30]$. Increased vascular permeability and endothelial injury contribute to the profound pathophysiological derangements in ALI [31,32]. If 


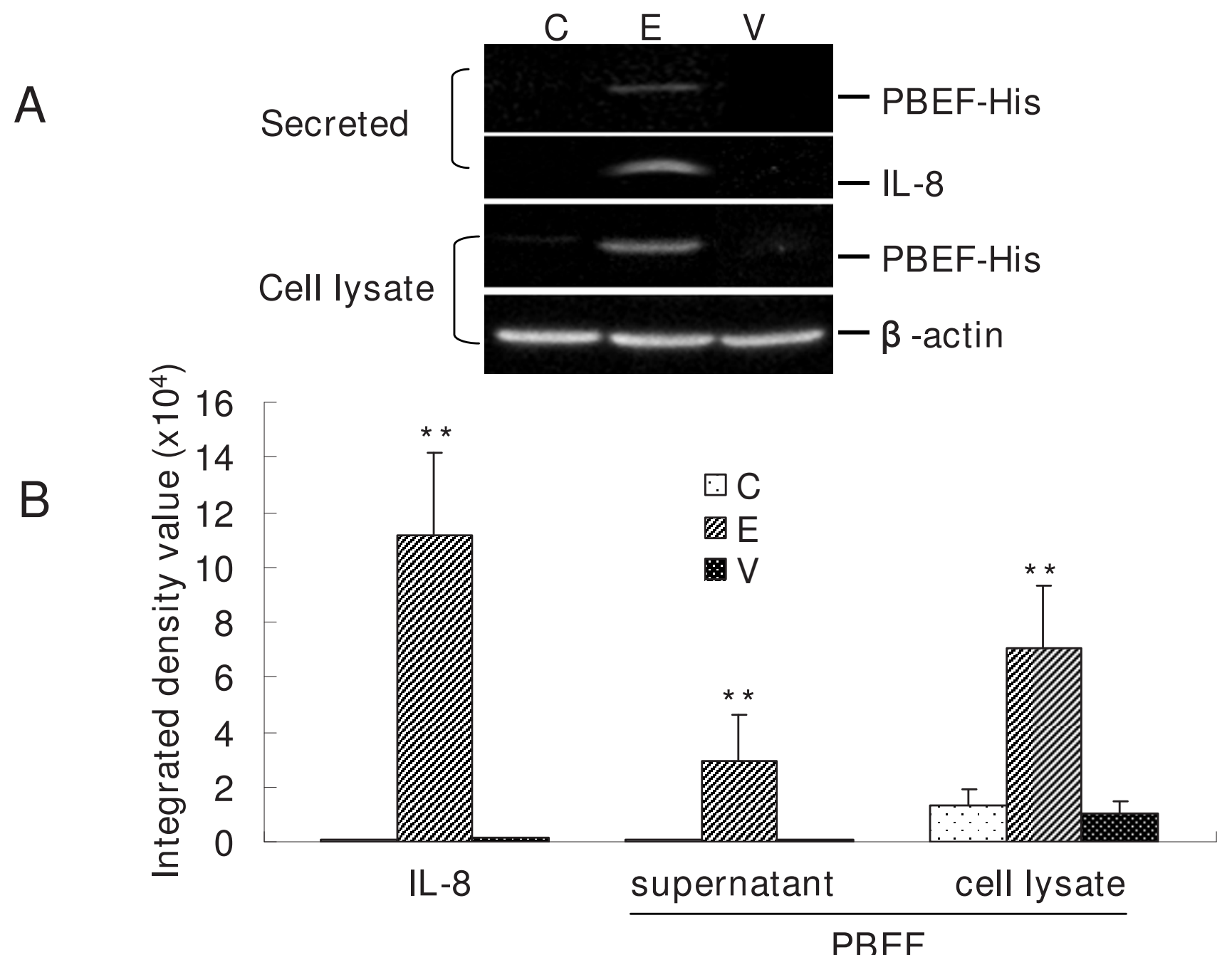

Figure 6

Effects of PBEF overexpression on IL-8 secretion and PBEF production in A549 cells. A. Representative western blotting image of PBEF and IL-8 protein detections. After starving for serum overnight, A549 cells were transfected with control (C), overexpressing construct pCAGGS-hPBEF (E) or vector pCAGGS (V) for 48 hours. Medium IL-8 and PBEF, Cell lysate PBEF and $\beta$-actin proteins were immunodetected as described in Figure I and Figure 2. B. Quantitation of PBEF and IL-8 protein levels by densitometric analysis. ${ }^{* *} \mathrm{p}<0.0 \mathrm{I}$ vs. control. C. representative western blotting image of PBEF and IL-8 protein detections with or without TNF $\alpha(I 5 \mathrm{ng} / \mathrm{ml})$ treatment. A549 cells were transfected with control (C), pCAGGS-hPBEF (E) or vector PCAGGS (V) for 48 hours, and then stimulated by TNF $\alpha$ (I $5 \mathrm{ng} / \mathrm{ml})$ for another 12 hours. Medium IL-8 and PBEF, cell lysate PBEF and $\beta$-actin proteins were immunodetected as described in above. D. quantitation of PBEF and IL-8 protein levels by densitometric analysis. $*^{*} p<0.01$ vs. control.

the alveolar epithelium is also damaged, the change in both endothelial and epithelial permeability could lead to major alveolar flooding with high-molecular-weight proteins, with prolonged changes in gas exchange, altered compliance and a much higher likelihood of disordered repair [33]. Normally, the lung alveolar epithelium forms an extremely tight barrier that restricts the movement of proteins and liquid from the interstitium into the alveolar spaces. In ALI, impaired alveolar epithelial function in the lungs is a marker of poor outcome in ALI [34]. A number of inflammatory cytokines, including TNF $\alpha$ and IL-8, can induce or aggravate the inflammation of endothelial and epithelial cells, leading to their barrier dysfunctions [35]. In this study we have demonstrated (Figure 7) that the TNF $\alpha$ stimulated increased in A549 cell permeability is significantly attenuated by the knockdown of PBEF expression by PBEF siRNA. Overexpression of PBEF increased A549 cell permeability in both basal and TNFa 


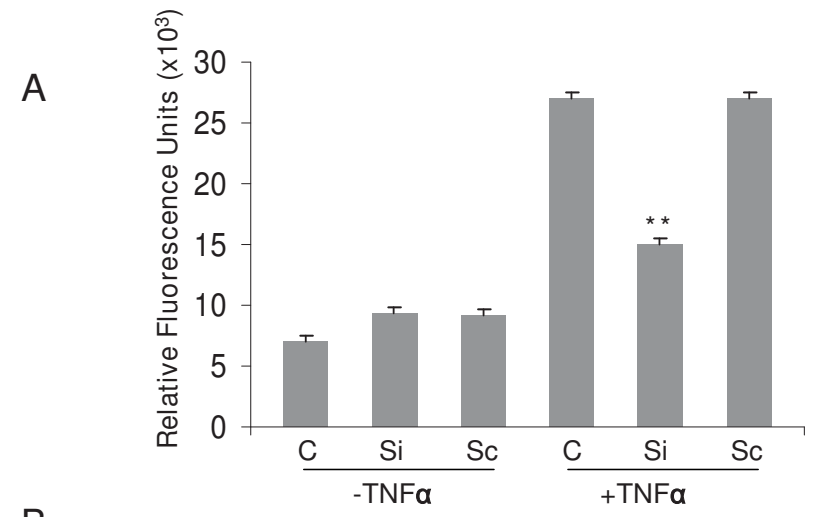

B

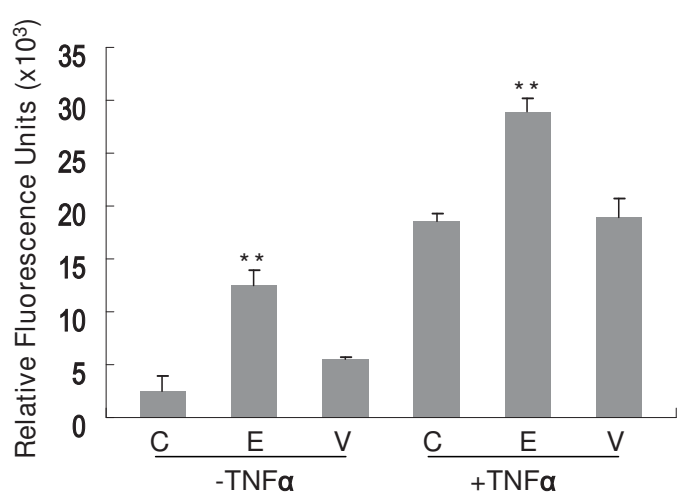

Figure 7

Effects of PBEF expression on in vitro cell permeability of A549 cells and HPAEC. A549 cells or HPAEC cells were seeded onto the culture inserts of permeability assay chambers and grown for $24 \mathrm{~h}$ before being transfected with the vehicle control (C), PBEF stealth siRNA (Si) or scrambled RNA (Sc), pCAGGS-hPBEF (E) or PCAGGS (V) for $48 \mathrm{~h}$ before treatment without or with $15 \mathrm{ng} / \mathrm{ml}$ TNF $\alpha$. Then, the FITC-Dextran reagent was added to each insert for $5 \mathrm{~min}$ at room temperature. Leakage of FITC-Dextran into the bottom chamber was assayed as described in the Methods. A\&C. Effects of PBEF underexpression on in vitro cell permeability of A549 cells and HPAEC; B\&D. Effects of PBEF overexpression on in vitro cell permeability of A549 cells and HPAEC. $*^{*} \mathrm{p}<0.0 \mathrm{l}$ vs. control.

induced conditions. These results suggest that PBEF may have an important role in epithelial cell barrier regulation. A549 cells are an alveolar Type II tumor epithelial cell line. While the type II epithelial cell only covers $7 \%$ of the alveolar surface area, it constitutes $67 \%$ of the epithelial cell number within the alveoli [36], pointing to its biochemical importance. The permeability increase of A549 cells in the TNFo-stimulated condition involves both paracellular permeability, with gap formation visualized by actin cytoskeleton staining, and basement membrane permeability [37]. Since A549 cells usually do not form a regular monolayer, we went to examine whether a similar effect can be observed in a primary HPAEC, which forms a typical monolayer. Indeed, we found that PBEF expression similarly affected the HPAEC permeability (Figure 7).

While an overexpression of PBEF results in an increased basal permeability, knocking down PBEF expression failed to alter the basal permeability both in A549 cells and HPAEC. It is possible that in our study, transfection of pCAGGS-PBEF engendered at least 3 fold higher PBEF protein expression, but transfection of PBEF siRNA only resulted in about $60 \%$ decrease of PBEF level, which might explain the subdued effect of the latter in the basal level. TNF $\alpha$ mediated effect may be partly due to its induction of IL-8 production. IL-8 has been demonstrated to induce actin fiber rearrangement and intercellular gap formation in endothelial cells [38]. IL-8 could have a similar effect on epithelial barrier function. Our previous study found that reductions in PBEF protein expression significantly attenuated endothelial barrier dysfunction induced by the potent edemagenic agent, thrombin, reflected by reductions in transendothelial electric resistance [7]. Furthermore, reductions in PBEF protein expression blunted thrombin-mediated increases in $\mathrm{Ca}^{2+}$ entry, polymerized actin formation, and myosin light chain phosphorylation [7], events critical to the thrombin-mediated permeability response [32]. Whether similar mechanisms account for the attenuating effects of PBEF knockdown on TNF $\alpha$ induced epithelial and endothelial cell barrier dysfunction remains to be elucidated in future studies.

\section{Conclusion}

In summary, this study demonstrated that TNF $\alpha$ significantly induced PBEF and IL-8 expression at both the mRNA and protein levels in A549 cells. PBEF-overexpression augmented IL-8 secretion and epithelial cell permeability in A549 cells, and the knockdown of PBEF expression by PBEF siRNA significantly blunted TNF $\alpha$ stimulated IL-8 secretion and mRNA production and attenuated TNF $\alpha$-induced cell permeability of A549 cells. Since inflammation and increased permeability is a hallmark of the pathogenesis of ALI, these results suggest that PBEF may play a critical role as an inflammatory cytokine in the dysregulation of alveolar epithelial cell barriers in the pathogenesis of ALI. These results lend further support to the potential of PBEF to serve as a diagnostic and therapeutic target in future studies of lung injury.

\section{Competing interests}

The authors declare that they have no competing interests.

\section{Authors' contributions}

HL, PL, JC, DF, RE carried out all studies and statistical analyses, and drafted the manuscript. BS, LZ and SY conceived of the study, and participated in its design and 
coordination. All authors read and approved the final manuscript.

\section{Acknowledgements}

This work was in part supported by NHLBI/NIH Grants IR0IHL080042OIAI (Ye, S.Q.) and HL073994 (Simon, B.A.), a Foundation for Anesthesia Education and Research Mentored Research Training Grant (Easley, R.B.), and the University of Missouri start-up fund (Ye, S.Q.).

\section{References}

I. Wheeler AP, Bernard GR: Acute lung injury and the acute respiratory distress syndrome: a clinical review. Lancet 2007: I553-64.

2. Calfee CS, Matthay MA: Nonventilatory treatments for acute lung injury and ARDS. Chest 2007, I 3 I (3):913-920.

3. Matthay MA, Zimmerman GA, Esmon C, Bhattacharya J, Coller B, Doerschuk CM, Floros J, Gimbrone MA, Hoffman E, Hubmayr RD: Future research directions in acute lung injury: summary of a National Heart, Lung, and Blood Institute working group. Am J Respir Crit Care Med 2003, 167:1027-1035.

4. Frank JA, Parsons PE, Matthay MA: Pathogenetic significance of biological markers of ventilator-associated lung injury in experimental and clinical studies. Chest 2006, I30(6): | 906-I4.

5. Ye SQ, Simon B, Maloney JP, Zambelli-Weiner A, Gao L, Grant A, Easley RB, McVerry B, Tuder RM, Standiford T, Brower R, Barnes K, Garcia JG: Pre-B-cell colony-enhancing factor as a potential novel biomarker in acute lung injury. Am J Respir Crit Care Med 2005, I 7 I(4):36I-370.

6. Bajwa EK, Yu CL, Gong MN, Thompson BT, Christiani DC: Pre-Bcell colony-enhancing factor gene polymorphisms and risk of acute respiratory distress syndrome. Crit Care Med 2007, 35: $1290-1295$

7. Ye SQ, Zhang LQ, Adyshev D, Usatyuk PV, Garcia AN, Lavoie TL, Verin AD, Natarajan V, Garcia JG: Pre-B-cell-colony-enhancing factor is critically involved in thrombin-induced lung endothelial cell barrier dysregulation. Microvasc Res 2005, 70(3):|42-5|.

8. Parsons PE, Matthay MA, Ware LB, Eisner MD, National Heart, Lung, Blood Institute Acute Respiratory Distress Syndrome Clinical Trials Network: Elevated plasma levels of soluble TNF receptors are associated with morbidity and mortality in patients with acute lung injury. Am J Physiol Lung Cell Mol Physiol 2005, 288(3):L426-3I.

9. Stüber F, Wrigge H, Schroeder S, Wetegrove S, Zinserling J, Hoeft A, Putensen $C$ : Kinetic and reversibility of mechanical ventilation-associated pulmonary and systemic inflammatory response in patients with acute lung injury. Intensive Care Med 2002, 28(7):834-4I.

10. Parsons PE, Eisner MD, Thompson BT, Matthay MA, Ancukiewicz M, Bernard GR: Lower tidal volume ventilation and plasma cytokine markers of inflammation in patients with acute lung injury. Crit Care Med 2005, 33:I-6.

II. Ranieri VM, Suter PM, Tortorella C, De Tullio R, Dayer JM, Brienza A, Bruno F, Slutsky AS: Effect of mechanical ventilation on inflammatory mediators in patients with acute respiratory distress syndrome: a randomized controlled trial. JAMA 1999, 282(I):54-6I.

12. Parsons PE, Eisner MD, Thompson BT, Matthay MA, Ancukiewicz M, Bernard GR, Wheeler AP, NHLBI Acute Respiratory Distress Syndrome Clinical Trials Network: Lower tidal volume ventilation and plasma cytokine markers of inflammation in patients with acute lung injury. Crit Care Med 2005, 33(I): I-6.

13. Park WY, Goodman RB, Steinberg KP, Ruzinski JT, Radella F, Park DR, Pugin J, Skerrett SJ, Hudson LD, Martin TR: Cytokine balance in the lungs of patients with acute respiratory distress syndrome. Am J Respir Crit Care Med 2001, I 64:1896-1903.

14. Korcheva V, Wong J, Lindauer M, Jacoby DB, lordanov MS, Magun B: Role of apoptotic signaling pathways in regulation of inflammatory responses to ricin in primary murine macrophages. Mol Immunol 2007, 44( I 0):276I-7I.

I5. Mukhopadhyay S, Hoidal JR, Mukherjee TK: Intravenous administration of activated protein $C$ in Pseudomonas-induced lung injury: impact on lung fluid balance and the inflammatory response. Respir Res 2006, I I (7): 125.

16. Adams JM, Hauser CJ, Livingston DH, Lavery RF, Fekete Z, Deitch EA: Early trauma polymorphonuclear neutrophil responses to chemokines are associated with development of sepsis, pneumonia, and organ failure. J Trauma 200I, 5 I:452-456.

17. Hudson LD: Causes of the adult respiratory di stress syndrome - clinical recognition. Clin Chest Med 1982, 3:195-2 I2.

18. Ware LB: Prognostic determinants of acute respiratory distress syndrome in adults: impact on clinical trial design. Crit Care Med 2005, 33(3 Suppl):2 17-222.

19. Matsushima K, Morishita K, Yoshimura T, Lavu S, Kobayashi Y, Lew W, Appella E, Kung HF, Leonard EJ, Oppenheim JJ: Molecular cloning of a human monocyte-derived neutrophil chemotactic factor (MDNCF) and the induction of MDNCF mRNA by interleukin I and tumor necrosis factor. J $\operatorname{Exp} M e d$ 1988, 167(6): 1883-93.

20. Mukaida N: Pathophysiological roles of interleukin-8/CXCL8 in pulmonary diseases. Am J Physiol Lung Cell Mol Physiol 2003, 284(4):L566-L577.

21. Folkesson HG, Matthay MA, Hebert CA, Broaddus VC: Acid aspiration-induced lung injury in rabbits is mediated by interleukin-8-dependent mechanisms. I Clin Invest 1995, 96: 107-I I6.

22. Yokoi K, Mukaida N, Harada A, Watanabe Y, Matsushima K: Prevention of endotoxemia-induced acute respiratory distress syndrome-like lung injury in rabbits by a monoclonal antibody to IL-8. Lab Invest 1997, 76:375-384.

23. Dunican AL, Leuenroth SJ, Grutkoski P, Ayala A, Simms HH: TNFalpha-induced suppression of PMN apoptosis is mediated through interleukin-8 production. Shock 2000, I 4:284-288.

24. Modelska K, Pittet JF, Folkesson HG, Courtney V, Matthay MA: Acidinduced lung injury. Protective effect of anti-interleukin-8 pretreatment on alveolar epithelial barrier function in rabbits. Am J Respir Crit Care Med 1999, I60: 1450-| 456.

25. Jia SH, Li Y, Parodo J, Kapus A, Fan L, Rotstein OD, Marshall JC: Pre$B$ cell colony-enhancing factor inhibits neutrophil apoptosis in experimental inflammation and clinical sepsis. J Clin Invest 2004, I I 3(9): I3 |8-27.

26. Ognjanovic S, Bao S, Yamamoto SY, Garibay-Tupas J, Samal B, BryantGreenwood GD: Genomic organization of the gene coding for human pre-B-cell colony enhancing factor and expression in human fetal membranes. J Mol Endocrinol 200I, 26: 107-II7.

27. Kendal CE, Bryant-Greenwood GD: Pre-B-cell colony-enhancing factor (PBEF/Visfatin) gene expression is modulated by NFkappaB and AP-I in human amniotic epithelial cells. Placenta 2007, 28(4):305- 14.

28. Ognjanovic S, Bryant-Greenwood GD: Pre-B-cell colony-enhancing factor, a novel cytokine of human fetal membranes. $\mathrm{Am} J$ Obstet Gynecol 2002, I 87(4): 105I-1058.

29. Bachofen A, Weibel ER: Alterations of the gas exchange apparatus in adult respiratory insufficiency associated with septicemia. Am Rev Respir Dis 1977, 1 16:589-6I5.

30. Bachofen M, Weibel ER: Structural alterations of lung parenchyma in the adult respiratory distress syndrome. Clin Chest Med 1982, 3:35-56.

31. Bachofen $\mathrm{H}$, Bachofen M, Weibel ER: Ultrastructural aspects of pulmonary edema. J Thorac Imaging 1988, 3(3): I-7.

32. Dudek SM, Garcia JG: Cytoskeletal regulation of pulmonary vascular permeability. J Appl Physiol 200I, 9 I (4):I487-500.

33. Liener UC, Brückner UB, Knöferl MW, Steinbach G, Kinzl L, Gebhard F: Chemokine activation within 24 hours after blunt accident trauma. Shock 2000, 17(3):169-172.

34. Parsons PE, Eisner MD, Thompson BT, Matthay MA, Ancukiewicz M, Bernard GR: Lower tidal volume ventilation and plasma cytokine markers of inflammation in patients with acute lung injury. Crit Care Med 2005, 33: I-6.

35. Thomas R, Martin NH, Morio N, Gustavo MB: Apoptosis and epithelial injury in the lungs. The Proceedings of the American Thoracic Society 2005, 2:214-220.

36. Leone AK, Chun JA, Koehler CL, Caranto J, King JM: Effect of proinflammatory cytokines, tumor necrosis factor-alpha and interferon-gamma on epithelial barrier function and matrix metalloproteinase-9 in Madin Darby canine kidney cells. Cell Physiol Biochem 2007, 19(1-4):99-1 I 2. 
37. Crapo JD, Barry BE, Gehr P: Cell number and cell characteristics of the normal human lung. Am Rev Respir Dis 1982, 126:332-337.

38. Lacherade JC, Van LA, Planus E, Escudier E, D'Ortho MP, Lafuma C, Harf A, Delclaux C: Evaluation of basement membrane degradation during TNF-alpha-induced increase in epithelial permeability. Am J Physiol Lung Cell Mol Physiol 200 I, 28 I (I):LI34-I43.

Publish with Bio Med Central and every scientist can read your work free of charge

"BioMed Central will be the most significant development for disseminating the results of biomedical research in our lifetime." Sir Paul Nurse, Cancer Research UK

Your research papers will be:

- available free of charge to the entire biomedical community

- peer reviewed and published immediately upon acceptance

- cited in PubMed and archived on PubMed Central

- yours - you keep the copyright

Submit your manuscript here:

http://www.biomedcentral.com/info/publishing_adv.asp
BioMedcentral 